\title{
STUDIES OF THE DEFENSE CONTRACTING PROCESS
}

\author{
Sumner Marcus*
}

Participation by private firms in the design and manufacture of weapons systems has increased enormously since the beginning of World War II. The increase has resulted both from a step-up in the amounts expended on defense as well as from the transfer of the major responsibility for defense production from public agencies to private firms.

In 1939, expenditures for defense by the federal government were only about a billion dollars and constituted only 1.2 per cent of the Gross National Product (GNP). At their peak during World War II they were \$8I billion and amounted to thirty-eight per cent of the GNP. In I948, even at their lowest postwar point, they were $\$ r 1.8$ billion or 4.5 per cent of the GNP. Since I955 they have amounted each year to between nine and ten per cent of a GNP now nearing the $\$ 600$ billion mark. ${ }^{1}$

Before World War II, arsenals operated by the federal government produced almost all Army ordnance items and a good share of Navy ordnance and ships. The only important class of articles produced exclusively by private firms was aircraft. During World War II, the bulk of weapons-making in all fields shifted to private firms and has stayed there. By 1958 , government-owned and operated facilities comparable to those of private defense contractors accounted for less than ten per cent of the resources devoted to weapons-making. ${ }^{2}$

Today a very substantial portion of the efforts of some of the largest firms in the country is devoted to contracts for products with a governmental end use. Large firms such as Republic Aviation Corporation, McDonnell Aircraft Corporation, and Grumman Aircraft Engineering Corporation sell less than ten per cent of their output to customers other than the government and its prime contractors. ${ }^{3}$

During the last few years, as might be expected, studies and analyses of the implications of these important changes in the defense procurement process have begun to appear in ever increasing numbers. Considering the social and economic importance of the subject, it is surprising that there were so few significant studies until quite recently. The subject has finally begun to command increasing attention, however, from a variety of academic disciplines as well as from the various governmental

- A.B. I931, M.B.A. I933, LL.B. I936, Harvard University; D.B.A. 1958, University of Washington. Professor and Chairman, Department of General Business, College of Business Administration, University of Washington.

${ }^{1}$ M. J. Peck \& F. M. Scherer, The Weapons Acguisition Process 100 (Ig62).

IId. at $98-99$.

- Weidenbaum, The Transferability of Defense Industry Resources to Civilian Uses, Statement Prepared for the Subcommitee on Manpower of the Senate Committee on Labor and Public Welfare 6-7 (Nov. 21, I963); see also Hannah, Government by Procurement, r8 Bus. Law. 997, 998 (1963). 
and private organizations concerned with the acquisition of weapons systems and other defense articles and services. The current knowledge of the field is now being enhanced constantly by the hearings and reports of congressional committees, by the reports of governmental agencies-the Department of Defense and its constituent agencies, the Comptroller General, the Bureau of the Budget-and by the studies of private organizations concerned directly and indirectly with the defense procurement process and the "remarkable political economic system" it has spawned. The present symposium makes a further significant contribution to our understanding of the nature and implications of the defense contracting process.

The purpose of this paper is to suggest the directions taken by studies of the postwar defense contracting process and to summarize some of their significant conclusions.

A meaningful analysis of studies of the defense contracting process requires at the outset some classification or breakdown of these studies by the purpose or objective. Accordingly, it is proposed to discuss previous studies of the defense contracting process under the following headings:

(x) studies of the law and procedure of defense contracting

(2) studies of how the defense contracting process actually operates

(3) studies of the impact of defense contracting upon the economy as a whole or upon some segment of the economy, such as small business, and

(4) studies of the political implications of the modern defense contracting process.

Studies of the Law and Procedure of the Defense Contracting Process

Studies of the defense contracting process until fairly recently have dealt mainly with the formal statutes, regulations, and directives describing the procedures employed by the government in acquiring articles and services from its private suppliers. This is not surprising in the light of the great volume and complexity of ever-changing regulations, particularly since the enactment of the Armed Services Procurement Act in 1948.4 Contracting officials, defense contractors, and other students of the defense contracting process have needed all the help that they could get even to begin to understand the outlines of the pertinent voluminous defense contracting regulations, let alone the more esoteric interpretations of them in specific cases.

Relatively few of these treatments of the formal law and procedures of defense contracting have attempted to cover the entire field. The earliest, and at this writing still perhaps the most comprehensive, is Navy Contract Law, prepared by members of the Office of the General Counsel of the Navy Department. ${ }^{5}$ The first edition was published in 1949; it was updated in 1959 and $x 96 \mathrm{r}$ and analyzes

6 62 Stat. 21 (I948), ro U.S.C. $\$ 230 x^{-1} 4$ (1958).

${ }^{5}$ U.S. Navy Dep't, Office of Generai Counsel, Navy Contract Law (2d ed. I959). 
both from an historical and contemporary point of view the formal procurement procedures employed by the contracting agencies of the three military services. The student of the defense contracting process will find it to be an excellent starting point for his researches into specific facets of the process. Later this year, there will also be available a multi-volume treatise on government contracts which one reviewer expects to be "the most comprehensive, all-embracing, and authoritative work in the government contracting field."

There is a rather substantial journal literature of varying quality concerning various facets of the defense contracting process. The character and volume of this have changed markedly since World War II when commentators on defense contractors concerned themselves mainly with the law and procedures of renegotiation and termination. By 1960 , we find articles dealing with the entire gamut of the defense contracting process. ${ }^{7}$ The current symposium, which deals with a very wide range of topics, does not even contain an article on renegotiation or termination. On the other hand, it treats the policies and formal procedures relating to fair employment, conflicts of interest, and small business, which are not as thoroughly understood. ${ }^{8}$

\section{II}

\section{Studies of How the Defense Contracting Process Operates}

The matter of how the pertinent laws and regulations have been applied to individual contractual transactions has not received as much attention from students of the defense contracting process as the regulations themselves. This has not resulted, however, from lack of interest. Rather, the information available to the student has been quite scanty due to the natural reluctance of the government and the defense industries, like suppliers and purchasers everywhere, to expose their activities to the gaze of those not immediately concerned with their transactions.

The procedures of contracting agencies and other governmental units concerned with the relationship between the defense industry and the government have tended to be like icebergs; only a relatively small part of them have been open to inspection. Notwithstanding the thousands of pages of government publications containing statutes, directives, regulations and instructions which assault and often confound the student of the procurement process along with its participants, they do not by any means answer all the important questions, and sometimes they may even give an erroneous impression of the policies and procedures that are actually employed.

- Cole, Review of McBride \& Wachtel, Law of Goverment Contracts, 23 Fed. B. J. 303 (I963).

${ }^{7}$ See Diamond, Indexed Bibliography of Articles on Government Contracts in Legal and Related Periodicals, 20 FED. B. J. 167 ( 1960 ). This is an excellent bibliography. Subsequent articles may be found in the Military Law Review, October, 1962; 32 Gro. WASF. L. REv. 23 (1963), and in various issues of the Federal Bar lournal.

${ }^{8}$ See U.S. NAvy DeP'T, op. cit. supra note 5, at $233-344$, for a full discussion of renegotiation and termination laws and procedures. 
An example of such an important discrepancy between formal regulation and practice has been in regard to the profit element included in the price of certain negotiated contracts. The regulations of the contracting agencies have always seemed to contemplate that contracting officers would take into consideration a variety of factors in determining the profit or fee element of the total price of a contract. These factors include the degree of risk assumed by the supplier, the nature of the work to be performed, the extent to which he received assistance from the government, the extent of the supplier's investment, the supplier's past performance in defense contracts, and the like. Since individual contracts varied greatly in respect to these various factors, it might have been assumed that there would be substantial variations in profits between various contracts awarded the same contractor and even greater variation between those awarded different contracts for different kinds of articles and services.

However, studies made in rg6r by Cherington and Scherer and in 1962 by the Logistics Management Institute confirmed what had been suspected right alongnamely, that it was "quite rare for negotiators to make any systematic evaluation" of these factors and that each contracting office developed historical patterns so that target profits tended to cluster closely around a norm for particular contractors and particular types of contracts. Moreover, there was no great difference between the highest and lowest target profits for all contractors of a particular class. The target profits for cost-plus-fixed-fee (CPFF) contracts ranged between 5.5 per cent and 7.5 per cent, for price-revision contracts between eight per cent and 9.5 per cent, and for firm fixed price contracts between ten per cent and twelve per cent. ${ }^{\theta}$ Discussions by representatives of Arthur D. Little, Inc. with defense contractors-perhaps concerning a later period-suggest that the profit for fixed price contracts was between nine and ten per cent. ${ }^{10}$

Defense agencies are not, of course, the only organizations which have different purposes and procedures than the ones described in their official publications and utterances. There are two circumstances, however, which militate particularly against greater disclosure of the way in which the defense contracting process works. One is that much of the effort of the agencies is concerned with the acquisition of weapons, the very identity and quantities of which must sometimes be concealed for purposes of national security. Perhaps even more important, however, is the traditional reluctance of buyers to disclose to their potential suppliers just how they carry on their business. This coming together of the traditions of military and industrial secrecy has doubtless contributed substantially to the failure of defense contracting agencies in the past to make more explicit just what they do and what the results of their efforts are.

Nor can the needed information be obtained readily from the defense contractors themselves. Even data on profitability of defense contracts is "extremely difficult to

- U.S. Dep't of Defense, Profits in Defense Contracting i-2 (Aug. 8, ig63).

${ }^{10}$ ARthuR D. LITTIE, INC., How Sick Is the Defense INDUSTRY? 43 (1963). 
obtain,"11 notwithstanding that the aggregate financial results of public corporations are usually available. One difficulty, of course, is that no breakdown is made between government and civilian business. This stems from the ordinary reticence of firms in a competitive market to disclose to their competitors or to their customer any more information than is necessary about their financial operations.

But all this has begun to change as the Congress and the top echelons of the Department of Defense have subjected the processes of the defense contracting agencies to closer scrutiny. Before I960, the only important governmental source of information concerning the prices and profits in the contemporary procurement process to which the public had access was the occasional investigation made by a congressional committee. ${ }^{12}$

The first comprehensive studies of contemporary procurement policies and practices were conducted by the Senate and House Armed Services Committees in I960. The hearings and reports of these committees which were based on these studies have provided much information for subsequent studies of the defense procurement process. ${ }^{13}$ More recently, in I962, the Senate Committee on Governmental Operations has made an extensive study of profits and costs in the missile procurement program. ${ }^{14}$ This is a substantial contribution to the relatively small pool of information concerning defense contracting. And in the same year the Joint Committee on Internal Revenue Taxation in its "Report on the Renegotiation Act of I95I" secured from the Renegotiation Board and made public important data concerning defense costs and profits which had not theretofore been made available. ${ }^{15}$

The most comprehensive non-governmental study to date has been that of the

${ }^{21}$ Id. at 43 .

${ }^{12}$ See, e.g., Hearings Before the Subcommittee for Special Investigations of the House Committee on Armed Services, on Aircraft Production Costs and Profits, 84 th Cong., $2 \mathrm{~d}$ Sess. (1956). See also the biennial and triennial inquiries since 1948 into the question of whether the control of defense profits should be continued. E.g., Hearings Before the House Ways and Means Committee on Extension of the Renegotiation Act, 86th Cong., rst Sess. (1959). Pricing and profit experience during World War II was studied at some length during the early postwar period, both by government agencies and individual scholars. While the findings and conclusions of these studies contributed substantially to an understanding of the procurement process in general, they did not purport to shed light on the problems or practices of postwar defense contracting. The leading governmental studies were U.S. Navy Dep't, History of Navy Department Renegotiation and Investigation of the National Defense Program, S. Rep. No. 440, Pt. 2, 8oth Cong., 2d Sess. (1948). Excellent analyses of these studies are contained in JoHn P. MiLLER, Pricing of Military Procurements (1949), and Parkin, Control of War Contract Profits, 26 Harv. Bus. REv. 230 (1948). There is also a good analysis of the British wartime experience in Wrulian Ashworth, Contracts and Finance (1953). In 1959 a symposium on renegotiation and defense profit policy was held. The arguments for and against the continuation of the renegotiation process in its existing form were explored in great detail by representatives of government and industry, and others. john F. Weston (Ed.), Procurement and Profit Renegotiation (x960).

${ }^{13}$ H.R. REP. No. 1959 and S. ReP. No. xg00, 86th Cong., 2d Sess. (1960). See particularly the procurement Presentation by the Department of Defense to the Procurement Subcommittee of the Senate Committee on Armed Services, Feb. 8-9, r960.

${ }_{14}$ Hearings Before the Permanent Subcommittee on Investigations of the Senate Committee on Government Operations, on Pyramiding of Profits and Costs in the Missile Program, 87 th Cong., $2 \mathrm{~d}$ Sess. (rg62).

${ }_{15}{ }^{\text {Joint }}$ Committee on Internal Revenue Taxation, Report on the Renegotiation Act of 195I, H.R. Doc. No. 322, 87th Cong. 2d Sess. $8 x-99$ (rg62). 
Weapons Acquisition Research Project of the Harvard Business School. The purpose of the three year project is "to determine the nature of the relationships between the government and weapons contractors in the acquisition of advanced weapons and to analyze the effects of these relationships on weapons acquisition and the speed and cost of their production."16 The first volume by Peck and Scherer presents an economic analysis of the weapons acquisition process and contains much valuable information concerning the process which would not be otherwise available.

A second recent study of importance is that of the Stanford Research Institute for the Aerospace Industries Association. ${ }^{17}$ It contains significant information obtained from the records of a number of aerospace companies as well as analyses of this and other available information of the type already mentioned.

Another recent study of importance is by the private consulting firm of Arthur D. Little, Inc. and designed to help their clients understand "the complex structure of the defense industry."18 The report contains many stimulating and provocative analyses and interpretations.

It is apparent from all these reports that one of the principal difficulties with existing defense contracting policies and procedures is the lack of guidelines. To one student, everything "seems open, fluid, and ad hoc."10 "It is doubtful . . . that anyone has a very useful view of what the 'public interest' is in the contract system." ${ }^{20}$ This is because many divergent public policies are involved in the administration of procurement. Some of them are squarely in conflict. The defense contracting official must decide in a given case whether his principal purpose is to accomplish a particular program in the aerospace field at the lowest cost to the government, or to be certain that governmental regulations are being fully observed in the expenditure of public money, or to help accomplish a broad national aim, such as economic growth or the maintenance of competition, or to make certain that no firm realizes excessive profits, or to insure the survival of a viable defense industry, or something else. ${ }^{21}$

As is always the case when several governmental agencies are assigned responsibility to carry out or to review a particular program, the principal role of the agency determines the relative emphasis given by the officials in that agency to the various public policy goals involved. Thus, it may be assumed that the defense contracting agencies have, in the past, and will continue in the future, to emphasize in their activities the importance of the development and acquisition of superior weapons systems. At the same time, it is also apparent from the recent studies in this field that procedures which have been developed in connection with the fixing and review

\footnotetext{
${ }^{16}$ PECK \& SCHERER, op. cit. supra note $\mathrm{I}$, at ix.

${ }^{17}$ Stanford Research INSTitute-The Industry-Government Aerospace Relationship (1963).

${ }^{18}$ ARThur D. Little, INC., op. cit. supta note ro, at iii.

${ }^{10}$ Stanford Research Institute, op. cit. supra note 17 , Pt. II, at 14 .

${ }^{20}$ Ibid.

${ }^{21}$ Ibid.; ARTHOR D. LITTLE, INC., op. cit. supra note 10, at 27.
} 
of the compensation of defense contractors may interfere with the achievement by the defense agencies of this basic objective.

In the first place, according to these studies, the viability of the defense industry is gradually being impaired by governmental measures which adversely affect and will continue to affect the profitability of the industry. There has been a long continuing debate between governmental officials, particularly officials of the Renegotiation Board, and the defense industry, concerning how profitable the industry has been. This debate has centered about the selection of the base employed to measure profitability. Those contending that the profits of the industry have been or are inadequate are impressed particularly by the low profit-sales ratios in the industry. And there is no question but that defense contractors' profits as a percentage of sales have declined steadily over the past few years. ${ }^{22}$ On the other hand, those who have regarded defense profits in past years as high, or even too high, point to the consistently higher than average return on net worth of the companies involved. Fortune reported that the return on sales in Ig6r of the aircraft industry (2.2 per cent) was the lowest of any of the twenty-one manufacturing industries, while the return on invested capital (II.6 per cent) was the third highest. ${ }^{23}$ The Renegotiation Board and the Tax Court have found profits of the aircraft industry to be "excessive" in some years in the past, largely because of this relationship between profits and net worth. ${ }^{24}$

Additional bases of comparison have been used in some of the recent studies of the defense industry and its relationship with the government. The Stanford Research Institute compared the return on total assets of the defense industry with that of a cross-section of industry because, in its opinion, such a rate provides a comprehensive measure of performance of how effectively, from a profit standpoint, all of the firm's economic resources are employed, and because it eliminates the effect of the particular financing method employed. The Institute found the industry's rate of return, measured in this way, to be below that of industry in general. ${ }^{25}$ The Little study, in making its comparisons, attempted to determine the contribution of government-furnished facilities to the profits of the industry and to evaluate the consequences to the industry of the decline in the amount of such facilities in the future which will result from changes in governmental policy. The report concluded that the impact of governmental assistance on profits has been great in the past. ${ }^{26}$ At the same time, the authors of the report "do not believe that the defense industry is on the brink of disaster," notwithstanding the probable continuation into the foreseeable future of the trends toward decreasing returns on sales and on equity, and the ever-rising requirements for funds for modernization, research, and replacement of government investment. ${ }^{27}$ Individual defense con-

\footnotetext{
22 ARTHUR D. LitTLE, INC., op. cit. stpra note 10, at 53.

${ }^{38} \mathrm{Id}$. at 54 .

${ }^{34} \mathrm{See}$, for example, Boeing Airplane Co. v. Renegotiation Board, 37 T.C. 6I3 (I962).

${ }^{25}$ StANFoRd Research INSTITUTE, op. cit. supra note I7, Pt. I, at 47-48.

${ }^{28}$ ARTHur D. Litrue, INC., op. cit. supta note Io, at 68.

${ }^{27}$ Id. at 85 .
} 
tractors who are inefficient, however, are likely to be "severely hurt" in the future. ${ }^{28}$

Another factor militating against the achievement of superior weapons systems is the failure to evolve a system of adequate incentives for optimal performance on the part of the defense industry. Notwithstanding an elaborate set of regulations designed to give contracting officials the utmost discretion in allowing substantial differentials between the compensation of the most efficient defense contractors and the least efficient, recent studies of the Department of Defense indicate that, in general, contracting officials adopt a target fee or profit for a given type of contract in a given industry and then proceed to use this target in arriving at the compensation for all contracts negotiated with the various firms of the industry. ${ }^{20}$ The study explains rather graphically how this comes about: ${ }^{30}$

Many contracting officers choose the expedient solution to their quandary: through experience, they arrive at a profit or fee rate that is well below the maximum permitted but high enough that the contractor will accept it, and they use these few rates over a long period for all contracts they negotiate, regardless of contractor or situation. As time goes on, they tend to lower the rate slightly, to establish themselves as good bargainers. The virtues of the "magic number" system are obvious: The contracting officer has little risk of spurring an investigation by the General Accounting Office if the rate is stable and trending downward, the contracting officer's superiors (who are in a poor position to evaluate the reasonable nature of the costs) are pleased at what appears to be hard bargaining, and finally, the contractor feels some sense of continuity-the known fee of today may be better than earnest negotiation on each contract may yield tomorrow. The drawback to this system is that it tends to become universal and ignores the individual characteristics of each situation.

The Department of Defense is hoping to get away from this undesirable uniformity by, among other things, requiring the use of a checklist and point system calculated to bring about the desired differences in treatment between various defense contractors. ${ }^{31}$ "Whether the program will succeed is questionable and, based on historical examples, unlikely."32

Incentives to good performance have also been minimized by the wide use of CPFF contracts during past years. Under these contracts, the compensation of contractors is not increased even if they make cost savings or produce a superior product. The Defense Department is now de-emphasizing contracts without incentives and encouraging the use of incentives in both fixed price and cost type contracts. $^{33}$ But this shift to other types of contracts is not likely to be a panacea. The incentive contracts which have been employed in defense contracting in the past have not always achieved their intended results. The defense contractor has

${ }^{28} \mathrm{Id}$. at $8 \mathrm{x}$.

${ }^{29}$ See p. 22, stupra.

${ }^{30}$ ARTHUR D. LITTLE, INC., op. cit. supra note Io, at 39.

81 This new approach was formally adopted by the Department of Defense in Armed Services Procurement Regulation Revision No. 2, Aug. 15, I963, and made effective on Jan. 1, 1964. ASPR $\$ 3-808$, 32 C.F.R. $\$ 3.808$ (Supp. 2963 ).

${ }^{32}$ ARTHUR D. LITTLE, INC., op. cit. supra note ro, at 80.

${ }^{83} 3 \mathrm{CCH}$ Gov't CONT. REP. I 80,020 ( $\mathrm{Ig}_{3}$ ). 
not been assured that he would make additional profits even when he has been able to perform the contract at less than the target cost. The aircraft industry, in particular, has been unhappy for a long time about judgments of the Comptroller General, the Renegotiation Board, and the Tax Court after the event that the performance of a contract at a cost below the target might have been due not so much to the efficiency of the contractor as to the initial setting of the target cost at an unrealistically high level. ${ }^{34}$ It must be concluded that the ability of incentive contracts to accomplish their basic purpose is put into serious question by the Little study. When the Department of Defense negotiates lower target fees for cost-plus-incentive-fee contracts than for cost type contracts without the incentive feature, "contractors are tending to bid at a cost they expect to underrun by a modest amount (if the competitive situation permits), so that they will collect sufficient incentive to come out at least as well as under a CPFF contract."35

If the defense contracting agencies have been unable to evolve completely satisfactory procedures for obtaining the maximum effort from the defense industry, it is not likely that other governmental agencies, less intimately concerned with the procurement process and having lesser responsibilities for the acquisition of superior weapons systems, will be more highly motivated in this regard. The General Accounting Office conceives its responsibility in regard to the defense contracting process to be mainly that of insuring literal compliance with procurement regulations and minimizing the profits of defense contractors. It is impossible to calculate the dampening effect which this powerful arm of the Congress has had upon the practices of both contracting officials and contractors. While they have doubtless been responsible for the recovery or prevention of unjustified profits from some contractors, they have also clearly encouraged uniformity in the treatment of contractors and have been responsible in part for the disregard by contracting officials, which we have noted, of the policies designed to discriminate through compensation in favor of the more efficient contractor. Other agencies, such as the Renegotiation Board, which enter the procurement process only tangentially, similarly may be expected to gear their policies to their primary mission of profit control, rather than to other objectives of the defense contracting process.

The health of the defense industry may be adversely affected by certain strategies which the defense firms themselves employ in vying for government business. Defense contractors frequently take a slightly lower fee on a large CPFF contract in order to make sure that they will be awarded it. This in turn becomes, in practice, the fee which they must accept on all subsequent contracts. ${ }^{36}$ Another unfortunate tendency is that of most defense contractors to expend substantial portions of their resources in attempting to land every contract in sight. This has resulted in a dilution of the efforts that could be expended on the performance of the contracts them-

${ }^{\mathrm{a} 4}$ Cf. Heyman, Contractual Problems in Contracting Out, 3I Geo. WAsr. L. REV. $77 \mathrm{I}$ (xg63).

${ }^{35}$ ARThur D. LiTTLE, INC., op. cit. supra note 10, at 80.

${ }^{36} I d$. at 43 . 
selves. Eighteen per cent of the aerospace industry's top scientific and engineering talent are working on proposals, of which seventy-five per cent are unsuccessful. ${ }^{37}$ This circumstance also accounts in part for the overcapacity of the industry which exists at the present time. ${ }^{38}$

\section{III}

\section{Studies of the Economic Impact of Defense Contracting}

In view of the importance of defense contracting to the economy, it is not surprising that there have also been studies of the precise significance of defense contracting to the economy as a whole, as well as studies of the impact of defense contracting upon the small business segment of the economy. The emerging possibility of partial disarmament has further enhanced the interest in these subjects during the past several years. ${ }^{39}$

As might be expected, for the most part these studies have been governmental studies. A good example of a study of the economic implications of defense purchasing is the staff report to the Subcommittee on Defense Procurement of the Joint Economic Committee; ${ }^{40}$ this describes in some detail the magnitude of current defense expenditures and the trends during the past quarter-century, the proportion of expenditures made by each of the various purchasing agencies, and the distribution of defense expenditures among the fifty states and among the principal defense contractors. ${ }^{41}$

Other congressional committees as well as private research organizations have begun to grapple with the difficult problems involved in transferring defense industry resources to civilian uses. A recent private study made for a congressional committee suggests how specialized, and therefore how difficult to convert to civilian uses, defense personnel and facilities are. Most defense resources are in a relatively few industry groups, which often are almost completely dependent upon defense contracts for their income. ${ }^{42}$

The significance of defense contracts to the welfare of small business has been studied continually for many years by the Small Business Committees of the Congress, the Small Business Administration, and other governmental agencies. Each year, the procurement agencies of the government publish the percentage of prime contracts going to small business firms. ${ }^{43}$ The percentage of prime contracts awards

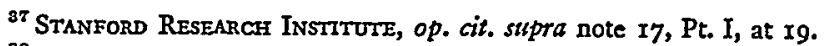

${ }^{38}$ ARthur D. LITTLE, INC., op. cit. supra note Io, at 86.

${ }^{8}$ See Emtre Benoit \& K. E. Boulding (Eds.), Disarmament and the Economy (1963).

${ }^{\circ}$ Staff of Joint Economic Comomttee, 86tr Cong., 2D Sess., Background Material on Economic Aspects of Military Procurement and Supply (Comm. Print ig60).

${ }^{11}$ Id. at 20-32.

12 WeIDEnBaum, op. cit. supra note 3 .

${ }^{48}$ A compilation of these reports may be found in Hearings Before the Senate Select Committee on Small Business on the Role of Small Business in Government Procurement, $1962-1963,87$ th Cong., 2d Sess. $35-47$ (1962).
} 
by the military agencies to small business firms rose again in 1962 after it had declined for several years. ${ }^{44}$

\section{IV}

\section{Studies of Sone Political Implications of the Defense Contracting Process}

Another type of study of the defense contracting process that has emerged recently is concerned with the political implications of the economic system in which government contracting plays such a large part.

Several recent studies have been concerned, in the first place, with the way that the ancient device of contract has been used to govern the defense contracting system, in which both the formal government and private firms play such highly significant but nontraditional roles. This system, which has been called both "government by contract" and "administration by contract," permits the bringing to the service of the government with relative rapidity established and proven work groups and talented individuals in highly specialized areas; also it is a method of accomplishing regulatory ends of the government which have little or nothing to do with the acquisition of defense materials and services. ${ }^{45}$

The contract has been used for centuries for a great variety of purposes because of its adaptability. It has been employed to order many diverse human relationships, as well as relationships between the citizen and the state. What distinguishes the use in 1964 of the contract device in defense contractor relationships from past uses of the contract is the vast amount of ground that it covers. Like the collective bargaining agreement between employer and union or the corporate charter and by-laws, the defense contract has become in effect a constitution which seeks to define in detail the roles of the parties concerned in the governance of the enterprise in which they are jointly engaged. ${ }^{46}$ To regard the defense contract as merely a special kind of sales contract or a special kind of employment contract is to misunderstand its true character. Not only does the contract set forth the description and performance requirements of the article or system being purchased, the compensation to be paid the producer, and the mode of payment; but in addition it spells out the many restrictions on the activities of the defense contractors. For example, they are required to pay their employees a specified minimum wage, not to discriminate in employment because of race, creed, color, or national origin, to use only materials of domestic origin, and to favor small business concerns in making purchases. The contract also spells out the management decisions which may require approval of, or initiation by, the government-such as decisions to change the specifications of the article being produced, to "make or buy," or to enter into subcontracts. Many defense contracts also differ substantially from the ordinary commercial contract in the power that

"H.R. REP. No. 2569, 87th Cong., 2d Sess. 49 (1963). The percentage of subcontract awards declined during the latter part of I962. 1962 SMALL Business ADMINISTRATION ANN. REP. 74 (1963).

${ }^{65}$ Miller, Administration by Contract, 36 N.Y.U.L. REv. 957, 958 (I96I).

${ }^{\circ}$ Cf. Richard S. F. Eels \& C. C. Whiton, Conceptual Foundations of Business 205, 209 (I96I). 
they give the government to adjust the compensation both during the performance of the contract and afterwards, as well as to examine the books and operations of the defense contractor in connection with such power. ${ }^{47}$

The defense contractor, moreover, is subject to regulations which may not even be contained in his contract. In a recent case, a construction contractor was held to be subject to the provisions of a termination clause not appearing in his contract but which was required to be incorporated in his contract by the applicable procurement regulations. ${ }^{48}$

One aspect of the wide use of contract to order this new, complex industrygovernment relationship-an aspect which has struck nearly all students-is the way that traditional lines between public and private enterprise have been blurred. ${ }^{40}$ On the other hand, it has been suggested that "the line between private and public action is blurred and always has been blurred in American law."

In any event, this casting of private industry and formal government into such an intimate relationship has evoked varied reactions. Some have had "laments for the passing of the age of economic freedom and complaints about the oppressiveness of government regulations and control." "Th1 "This lack of a clear-cut separation of public and private authority and responsibility offends some people." ${ }^{262}$ At the very least, it is asserted that, if the system is to be continued, the power of defense agencies to achieve unrelated social goals through contract provisions should be circumscribed by the restrictions normally applicable to government regulations, such as the Administrative Procedure Act. ${ }^{53}$

A leading student of the relations between government and society has this to say: ${ }^{54}$

The basic question bearing on the desirability of the system is whether the already vastly complex purchasing system should be further complicated by what are, in the final analysis, political considerations ... cluttering up procurement contracts with irrclevancies .... In the main, there is little justification for continuing to regulate by contract.

${ }^{47}$ A good summary statement of the purpose and content of defense contract provisions is contained in Navy Contract Law, op. cit. supra note 5, c. 9. See also Miller, supra note 45, and Whelan \& Pearson, Underlying Values in Government Contracts, 10 J. Pus. L. 298 (1961).

${ }^{48}$ G. L. Christian and Associates v. United States, 312 F.2d 418 (Ct. Cl. 1963), cert. denied, 375 U.S. 954 (1963). See Comment, Contract by Regulation, 32 Geo. WasH. L. Rev. III (I963).

${ }^{40}$ Stanford RESEARCh INSTrTute, op. cit. supra note 77 , at 18 . See also Dupré \&z Gustafson, Contracting for Defense: Private Firms and the Public Interest, 77 Pox. Scr. Q. 161, 176 (1962); Miller, supra note 45, at 989; Cleveland, in Hartan Cleveland and Others (Eds.), Ethics aNd Bigness, at XXV (I962); Heyman, Government by Contract: Boon or Boner?, 21 PUB. ADMIN. REv. 59 (I961); Edward S. Mason, The Corporation IN MODERN SOCiety I7 (I959).

${ }^{50}$ Miller, supra note 45, at 957; Eugene V. Rostow, Planning for Freedom: The Pumlic Law of American Capitalism 336 (1959).

${ }^{51}$ STANFORd RESEARCH INSTITUTE, op. cit. supta note 17, Pt. II, at $\mathrm{x}$. "The division between state and private life, between command and contract, is blurred and replaced by an image of the constitutional state permeating all society." Cf. Losos, The Impact of the Fourtecnth Amendment Upon Private Law, 6 ST. Louts U. L.J. 368,377 (196r).

${ }_{52}$ Mason, op. cit. supra note 49 , at 18.

${ }^{58} 60$ Stat. 243 (1946), 5 U.S.C. \$ roor et seq. (1958); Hannah, stpra note 3, at 1015.

${ }^{54}$ Miller, supra note 45, at 965 . 
On the other hand, for some students of the defense contracting process, governmental intervention of the kind described is regarded as not only desirable but as an absolute necessity, particularly when the government designates a private firm as the manager of an entire weapons system program. "[Since] business is no longer merely a supplier but a participant in the management and administration of a public function" through its function of placing extensive subcontracts, private firms "must ultimately become accustomed to close supervision with the resulting investigations, audits, and other paraphernalia that accompany the spending of taxpayers' money."

Whether or not the amount of governmental control now exercised is, in their opinion, the right amount, there seems to be a consensus among students of the procurement process that the contract system is "probably here to stay" since no more acceptable method has been conceived. ${ }^{56}$

\section{Conclusion}

The studies of the defense contracting system which have been discussed above, and the present symposium, are clearly only the forerunners of a vast literature in the field. Some of the groups which have already contributed substantially to our understanding of the subject are continuing their efforts. In addition other organizations are about to enter the field.

Obviously effective public policy decisions affecting the defense contracting system will not be possible without an understanding of the relevant facts concerning the system. Until very recently, congressional hearings were marked far more by the heat they gave out than by the light they shed on these difficult subjects; now this is fortunately all changing. This change not only augurs well for public policy but also permits the student of government-business relationships in the production of weapons systems to look ahead with some confidence to the continued availability of significant data about this most interesting chapter in the environmental studies of business. ${ }^{57}$

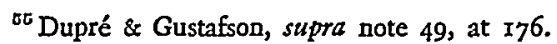

${ }^{60}$ Stanford Research InStitute, op. cit. supra note $\mathrm{I} 7$, Pt. II, at I8; Miller, supra note 45 , at 967. The situation in regard to government contracting for research and development is analyzed in a recent report, U.S. Bureau of the Budget, Report to the President on Government Contracting for Research and Development, [the Belx REPORT], S. Doc. No. 94, 87th Cong., $2 \mathrm{~d}$ Sess. (1962). There is an excellent bibliography, id. at 69 .

${ }^{57}$ Excellent bibliographies of books, articles, and reports on the defense contracting process are contained in Stanford Research INSTTtUTE, op. cit. supra note 17 , Pt. II, at 285-318: ARThUr D. LITTLE, INC., op. cit. supra note I0, at 89-93, and PECK \& SCHERER, op. cit. supra note I, at 712-25. In addition, significant studies in the field are now being conducted by the Brookings Institute and the Logisties Management Institute. 